\title{
The Long-Run Benefits of Sustained Low Inflation
}

\author{
Richard G. Anderson
}

$\mathbf{P}$ olicymakers at the Federal Reserve wage preemptive wars against inflation; that is, they tend to tighten monetary policy during economic expansions before incoming data confirm an increased rate of inflation. Today, many market analysts believe the Federal Open Market Committee is nearing the end of its most recent preemptive strike. Hence, it seems worthwhile to review the benefits that flow from sustained low inflation.

A common theme among Fed officials is that price stabilitytypically defined as an inflation rate that is sufficiently low, stable, and predictable so as not to be a factor in decisionmaking-is a prerequisite for attaining maximum sustainable economic growth. In his closing remarks at the August 2005 Federal Reserve Bank of Kansas City policy conference, Chairman Greenspan said, "I presume maximum sustainable economic growth will continue to be our goal, with price stability pursued as a necessary condition to promote that goal." Incoming Fed Chairman Bernanke (2005) has written: "[T]he low-inflation era of the past two decades has seen not only significant improvements in economic growth and productivity but also a marked reduction in economic volatility, both in the United States and abroad, a phenomenon that has been dubbed 'the Great Moderation'...[A]s I have argued elsewhere, there is evidence for the view that improved control of inflation has contributed in important measure to this welcome change in the economy."

Typically, policymakers' desired long-run inflation rate is a slow increase in a broad index of consumer prices, excluding food and energy. In part, the non-zero rate reflects an assumed measurement bias due to imperfect adjustment for quality change and the introduction of new goods; in part, the rate also embeds a cushion against the risk that an adverse shock might corner policymakers against the zero lower bound on nominal interest rates.

The costs of sustained inflation at such a low rate primarily are of two types. First, "monetary costs" arise as inflation reduces the real return on money, inducing firms and households to needlessly incur additional costs to more closely manage their monetary assets. Inflation also muddies price signals by increasing the difficulty of distinguishing temporary changes in goods' prices from permanent changes. Higher inflation also tends to attract real resources, including new college graduates, into professions such as law and financial services that benefit by creating hedges and shelters against inflation.
In empirical studies, however, the estimated costs of moderate inflation (versus an inflation rate low enough to be equated to price stability) are small, often less than three-hundredths of 1 percentage point of annual GDP growth; see the papers by Bruno and Easterly (1996) and Barro (1996). But this opinion is not universally held. Dotsey and Ireland (1996) present a model in which the combined impact of several effects, each individually small, is large. Second, and perhaps more significant, are distortions due to the nominal nature of the U.S. tax system. Studies in Feldstein (1999) and by Bullard and Russell (2004) suggest that the level of real output is lower by approximately one-half to 1 percent for each 1 percentage point that the inflation rate is above that associated with price stability. Yet, cross-country empirical studies suggest little, if any, effect on output when inflation is less than 15 to 40 percent per year.

In short: Measures of the trade-off between sustained inflation and long-run economic growth remain extremely uncertain, as evidenced in the recent conference volume by the Bank of Japan (2004). Yet, almost uniformly, central bankers argue that sustained low inflation, at a rate no greater than that defined as price stability plus a small cushion to avoid the zero lower bound on nominal interest rates, is a prerequisite to realizing an economy's maximum long-run economic growth. Fortunately, recent surveys of inflation expectations in the United States suggest that the public is confident the Federal Reserve will sustain such an environment of low, stable inflation.

\section{A longer essay on this topic is available on the author's web page at http://research.stlouisfed.org/econ/anderson/ Essay_CostsOfInflation.pdf.}

Bank of Japan. Conference proceedings: "Sustained Economic Growth and Central Banking." Monetary and Economic Studies (Special Edition), December 2004.

Barro, Robert. "Inflation and Growth.” Federal Reserve Bank of St. Louis Review, May/June 1996, 78(3), pp. 153-69.

Bernanke, Ben S. "What Have We Learned Since October 1979?" Federal Reserve Bank of St. Louis Review, March/April 2005, 87(2, Pt. 2), pp. 277-82.

Bruno, Michael and Easterly, William. "Inflation and Growth: In Search of a Stable Relationship." Federal Reserve Bank of St. Louis Review, May/June 1996, 78(3), pp. 139-46.

Bullard, James B. and Russell, Steven. "How Costly Is Sustained Low Inflation for the U.S. Economy?” Federal Reserve Bank of St. Louis Review, May/June 2004, 86(3), pp. 35-67.

Dotsey, Michael and Ireland, Peter N. "The Welfare Cost of Inflation in General Equilibrium.” Journal of Monetary Economics, 1996, 37(1), pp. 29-47.

Feldstein, Martin. The Costs and Benefits of Price Stability. Chicago: University of Chicago Press, 1999. 